\title{
Food, pregnancy and lactation
}

\section{Dietary guidelines for pregnant women}

\author{
Rosa M Ortega* \\ Department of Nutrition, Faculty of Pharmacy, Complutense University of Madrid, E-28040 Madrid, Spain
}

\begin{abstract}
The nutrition of pregnant women is decisive in the course of gestation and the health of both mother and child. However, in the Spanish population, clinical monitoring of nutrition is rare, the control of bodyweight receiving most attention. Many studies show that pregnant women take too much fat and too little carbohydrate, and that intakes of fibre and several trace elements are lower than recommended.

Although many people think they know what a correct (varied and balanced) diet is, the concept is often misleading. Generally, they do not match the ideal theoretical framework for achieving an adequate energy profile of the diet. Neither do they facilitate intakes of vitamins and minerals close to recommended levels. Nutrition education programmes are therefore required to explain adequate dietary guidelines to pregnant women, and indeed to all women of childbearing age.

Considering the criteria suggested by a number of researchers concerning the number of food portions from each food group that pregnant women should include in their diets, the following guidelines for daily consumption are proposed: 3-4 portions of milk products, $2-3$ portions of meat, fish or eggs, and 3 portions of fruit, $4-5$ portions of vegetables or greens and $7-8$ portions of cereals and legumes (a portion is defined as the amount of food that would be found on an average plateful or the normal units of consumption of a food).
\end{abstract}

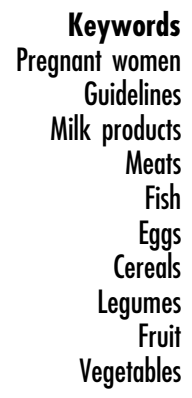

The improvement of nutritional status, both before conception and during gestation, can help to prevent maternal complications such as nausea, vomiting, diabetes, hypertension, eclampsia, bone demineralisation, obesity, etc. It can also help protect against premature birth, low birth-weight and congenital malformations. Because of the associated benefits and low cost/efficiency ratio, encouraging proper nutrition should be considered a priority ${ }^{1}$.

During pregnancy, energy intake should be increased in a proportion well below the increase required for the intake of nutrients ${ }^{1,2}$ (Table 1). Thus, food habits should be modified in order to achieve a higher nutrient density in the diet ${ }^{1}$. With respect to the different food groups, the following comments might be taken into account.

\section{Milk products}

These are an important source of nutrients whose intake should be increased during pregnancy. In particular, milk products are good sources of calcium and riboflavin ${ }^{1}$.

During pregnancy, calcium intake is usually below that recommended $^{3,4}$, and even worse in women who also smoke. Women smokers are known to take less milk products, calcium and vitamin $\mathrm{D}$ than non-smokers ${ }^{4}$. Insufficient intake of milk products can negatively affect the mother's bone mineral content and increase the risk of osteoporosis later in life $\mathrm{e}^{1,5}$. It is also associated with lower calcium content in the skeleton of the foetus ${ }^{5}$.

One study on Spanish pregnant women showed calcium intakes below $1100 \mathrm{mg}$ day $^{-1}$ in $70.2 \%$ of cases. Although this did not modify calcaemia, it later influenced calcium content of maternal breast-milk $\left(5.95 \pm 1.56 \mathrm{mmol}^{-1}\right.$ in breast-milk of mothers with calcium intakes $<1100 \mathrm{mg}$ day $^{-1}, 6.82 \pm 1.31 \mathrm{mmoll}^{-1}$ in that of mothers with higher intakes) ${ }^{6}$. This suggests that infants of women who took insufficient milk products during pregnancy had lower bone mineral content at birth and also get less calcium via maternal breast-milk ${ }^{6}$.

Several studies have related low milk product consumption and low calcium intake with an increased risk of gestational hypertension ${ }^{5,7}$. In a group of Spanish pregnant women, those who suffered hypertension (7.3\%, after excluding those with other complications indicative of pre-eclampsia) had lower calcium intakes $\left(757.7 \pm 154.5 \mathrm{mg} \mathrm{day}^{-1}\right.$ ) than normotensive pregnant subjects $\left(986.4 \pm 502.3 \mathrm{mg}\right.$ day $^{-1}$ ). The relationship between calcium intake and blood pressure was 
Table 1 Recommended intakes of energy and nutrients for pregnant women ${ }^{2}$

\begin{tabular}{lccc}
\hline & $\begin{array}{c}\text { Adult woman } \\
20-39 \text { years old }\end{array}$ & $\begin{array}{c}\text { Second half } \\
\text { of pregnancy } \\
20-39 \text { years old }\end{array}$ & $\begin{array}{c}\text { Increment with respect } \\
\text { to non-pregnant } \\
\text { woman }(\%)\end{array}$ \\
\hline Energy $(\mathrm{kcal})$ & 2300 & 2550 & 10.9 \\
Protein $(\mathrm{g})$ & 41 & 56 & 36.6 \\
Calcium $(\mathrm{mg})$ & 800 & 1400 & 75 \\
Iron $(\mathrm{mg})$ & 18 & 30 & 66.7 \\
lodine $(\mu \mathrm{g})$ & 110 & 135 & 22.7 \\
Zinc $(\mathrm{mg})$ & 15 & 20 & 33.3 \\
Magnesium $(\mathrm{mg})$ & 330 & 450 & 36.4 \\
Vitamin $\mathrm{B}_{1}(\mathrm{mg})$ & 0.9 & 1.0 & 11.1 \\
Vitamin $\mathrm{B}_{2}(\mathrm{mg})$ & 1.4 & 1.6 & 14.3 \\
Niacin $(\mathrm{mg})$ & 15 & 17 & 13.3 \\
Vitamin $\mathrm{B}_{6}(\mathrm{mg})$ & 1.6 & 2 & 25 \\
Folate $(\mu \mathrm{g})$ & 400 & 600 & 50 \\
Vitamin $\mathrm{B}_{12}(\mu \mathrm{g})$ & 2 & 2.2 & 10 \\
Vitamin $\mathrm{C}(\mathrm{mg})$ & 60 & 80 & 33.3 \\
Vitamin $\mathrm{A}(\mu \mathrm{g})$ & 800 & 800 & 0 \\
Vitamin $\mathrm{D}(\mu \mathrm{g})$ & 5 & 10 & 100 \\
Vitamin $\mathrm{E}(\mathrm{mg})$ & 12 & 15 & 25 \\
\hline
\end{tabular}

independent of body mass index, the number of previous pregnancies, age and haematocrit levels ${ }^{7}$.

Milk products are also important sources of riboflavin. This vitamin, as well as acting as a coenzyme in energy use (which makes it necessary for foetal growth), is also a cofactor of glutathione reductase. It is therefore considered an indirect antioxidant ${ }^{8}$. One study, in which 57 women were followed during pregnancy and lactation, showed that women with vitamin $\mathrm{B}_{2}$ intakes below recommendations $(43.9 \%)$ took less dairy products $\left(305.2 \pm 88.5 \mathrm{~g} \mathrm{day}^{-1}\right.$ compared with $507.9 \pm 137.2 \mathrm{~g}$ day $^{-1}$ in those with higher riboflavin intakes). Later, during lactation, in this group of women both their transition and mature breast-milk had lower content in vitamin $\mathrm{B}_{2}{ }^{9}$.

Considering these data, most authors ${ }^{10-12}$ agree on the recommendation for increased consumption of milk and dairy products during pregnancy, from the $2-3$ portions per day for the general population, to $3-4$ portions per day (Table 2).

\section{Meat, fish and eggs}

Adequate supply of polyunsaturated fatty acids, especially those such as docosahexaenoic, which can influence the formation of structures of the nervous system and retina of newborn infants ${ }^{13}$, is of utmost importance. Bearing in mind the characteristics of the average Spanish diet ${ }^{3,4}$, it seems advisable to increase fish consumption during pregnancy.

Some authors have also recommended increasing the intake of eggs during gestation, since they are important providers of nutrients and the best source of lecithin or phosphatidylcholine, which supplies choline (a compound of great physiological importance) $)^{14}$. Recent studies have suggested that pregnant women should take some $450 \mathrm{mg} \mathrm{day}^{-1}$ of choline ${ }^{15}$.

Increasing fish and egg consumption over usual diet $\mathrm{d}^{3,4}$ can also contribute to adequate vitamin $\mathrm{D}$ intake necessary for the correct use of calcium and average population intakes are often below recommended ${ }^{3,4}$.

Table 2 Dietary guidelines for pregnant women

\begin{tabular}{lcl}
\hline & $\begin{array}{c}\text { Portions recommended } \\
\text { per day }\end{array}$ & \multicolumn{1}{c}{ Mean size of portion } \\
\hline Milk products & $3-4$ & $\begin{array}{l}\text { Milk: } 200 \mathrm{ml} \\
\text { Yoghurt: } 125 \mathrm{~g}\end{array}$ \\
& & $\begin{array}{l}\text { Non-matured cheese: } 30-40 \mathrm{~g} \\
\text { Other cheeses: } 15-30 \mathrm{~g} \\
\text { Meat: } 100-125 \mathrm{~g}\end{array}$ \\
Meat, fish, eggs & $2-3$ & $\begin{array}{l}\text { Fish: } 125-150 \mathrm{~g} \\
\text { Eggs: } 1\end{array}$ \\
Fruit & 3 & $\begin{array}{l}\text { Of medium size } \\
1 \text { glass of juice }(150 \mathrm{ml})\end{array}$ \\
Vegetables \& greens & & $\begin{array}{l}100-200 \mathrm{~g} \text { when raw } \\
\text { Bread: } 30-40 \mathrm{~g}\end{array}$ \\
Cereals \& legumes & $4-5$ & $\begin{array}{l}\text { Breakfast cereals: } 30-40 \mathrm{~g} \\
\text { Rice, pasta, legumes: } 50 \mathrm{~g} \text { before cooking }\end{array}$ \\
& $7-8$ &
\end{tabular}


Adequate exposure to sunlight helps guarantee a good vitamin D status ${ }^{13}$.

The risk for excess vitamin A intake should be considered in developed countries, which has been associated with miscarriages and teratogenic effects (cardiovascular, facial and nervous system malformations $)^{13}$. During pregnancy, the consumption of liver, which is rich in vitamin $\mathrm{A}$, should be avoided ${ }^{13}$.

The need for additional protein is obvious, given the intense synthesis of tissues both maternal and foetal. Fortunately, the mean Spanish diet is rich in high-quality proteins $^{3,4,13}$. Smolin and Grosvenor ${ }^{12}$, in their proposals for modifying the 'Food Guide Pyramid' for pregnant women, suggested 2 portions per day of meat, fish or eggs, but of slightly bigger size (170 g instead of $140 \mathrm{~g}$ ). Considering these recommendations and the criteria suggested by Allen and Casterline ${ }^{11}$, a daily consumption of 2-3 portions of these foods seems reasonable (Table 2).

\section{Cereals}

In general, the consumption of cereals by Spanish mothers-to-be is quite $\operatorname{low}^{3,4}$. An increased presence of these in the diet could help adjust energy profiles (usually unbalanced with too much fat and protein and little carbohydrate), and improve the intakes of fibre, vitamins and minerals, which are usually below recommended $3,4,6,7,9$.

Cereals provide important amounts of vitamin E, which plays an important role in the final success of pregnancy. Women with low vitamin E levels more frequently have premature babies, with low birth-weight and at greater risk of haemolytic anaemia ${ }^{1,8}$. Vitamin $\mathrm{E}$ deserves special attention since many pregnant women take less than recommended, some studies ${ }^{16}$ suggest up to $81.5 \%$.

Cereals, nuts and legumes are also important sources of zinc and magnesium, minerals often present in diets below recommendations ${ }^{3,4}$. Their deficit has been associated with an increased risk of hypertension and other problems of gestation ${ }^{1}$.

Some authors recommend consumption of approximately 4 portions per day of cereals, preferably wholegrain cereals ${ }^{10}$. Others recommend a minimum daily number of portions of $7^{11}$ or even $8^{12}$.

\section{Fruit}

Along with vegetables, fruits are an important source of vitamins and minerals. They provide antioxidants, especially vitamin $\mathrm{C}$ and $\beta$-carotenes ${ }^{13}$, which are essential during pregnancy.

Ascorbic acid deficiency is associated with an increased risk for infections, premature birth and pre-eclampsia ${ }^{13}$. Although the Spanish diet is quite rich in this vitamin, some studies suggest that a proportion of pregnant women (12-21.1\%) take less than recommended amounts $^{3,4,17}$. In one group, $21.2 \%$ of women were found in this category ${ }^{17}$. These women ate less fruit $\left(148.8 \pm 78.9 \mathrm{~g} \mathrm{day}^{-1}\right.$ compared with $398.1 \pm 221.9 \mathrm{~g}$ day $^{-1}$ for women who ate adequate amounts) and vegetables $\left(145.5 \pm 44.9 \mathrm{~g} \mathrm{day}^{-1}\right.$ compared with $275.1 \pm$ $104.9 \mathrm{~g} \mathrm{day}^{-1}$ among those whose vitamin $\mathrm{C}$ intake was adequate). Their serum vitamin C levels were less satisfactory. Later, their transition milk content of vitamin C was lower $\left(255.5 \pm 220.3 \mu \mathrm{moll}^{-1}\right.$ compared with $437.8 \pm 288.4 \mu^{m o l l}{ }^{-1}$ for those with better vitamin $\mathrm{C}$ intakes) ${ }^{17}$.

At birth, the child passes from a low-oxygen to a highoxygen environment. Consequently, the risk of peroxidation damage is increased ${ }^{8}$. Vitamin $\mathrm{C}$ deficiency could lead to inadequate antioxidant defence. Moreover, the lower vitamin $\mathrm{C}^{18}$ and $\mathrm{E}^{16}$ concentrations in the milk of smoking mothers could mean their children face an even greater challenge.

A minimum of 2 portions of fruit a day seems advisable, as suggested by most authors ${ }^{11}$. Smolin and Grosvenor ${ }^{12}$ advise 3 portions per day.

\section{Vegetables}

These are foods with high nutrient densities and pregnant women should take as a minimum the recommended 3-5 portions per day for the general population ${ }^{11}$; Smolin and Grosvenor $^{12}$ advise a minimum of 4 portions daily for pregnant women. Increasing consumption of fruits and vegetables is especially useful for hypermesis during pregnancy $^{10}$.

Undoubtedly, unless $4-5$ portions of these foods are taken daily, it is impossible to reach the $600 \mu \mathrm{g} \mathrm{day}^{-1}$ of folic acid recommended for pregnant women (Table 2). In terms of Spanish culinary tradition, it is difficult to get this many vegetables into the diet. However, it is proposed as an ideal - although it might also be a good idea to keep up with folate supplements ${ }^{3,4}$, to prevent deficiencies. Inadequate supply of folic acid during pregnancy is associated with low birth-weight, premature dislodging of the placenta, neural tube defects and other congenital malformations ${ }^{1,10}$. In Spanish pregnant women, the intake of this vitamin is frequently lower than it should be $\mathrm{b}^{3,4}$. Intake is even lower amongst those who smoke ${ }^{4}$. It is therefore necessary to advise people on the importance of increasing consumption of fruit and vegetables, especially before and during pregnancy.

\section{Final considerations}

What a woman eats during pregnancy should cover her nutritional requirements, facilitate optimum growth of the foetus, prepare the body for a birth without complications and contribute to a satisfactory lactation period ${ }^{1}$. Given 
that energy intake need only be raised a little, while nutrient intake must be increased much more, it would be advisable to lower fat and simple carbohydrate intakes and increase those of fruit, vegetables, greens and legumes ${ }^{10}$. The diet of pregnant women should be varied, balanced and gastronomically satisfactory ${ }^{10}$. Since nutrition is crucial during this stage of life, the establishment and dissemination of guidelines that help to bring intakes closer to theoretical ideals deserve high priority.

However, proposed dietary guidelines are not only generally not followed by the population, most women of childbearing age don't even know they exist. They therefore frequently go through pregnancy with nonideal nutritional status ${ }^{19}$.

Bearing in mind the criteria suggested by a number of authors concerning the number of food portions from each food group that pregnant women ought to take, the following guidelines for daily consumption are proposed: 3-4 portions of milk products, $2-3$ portions of meat, fish or eggs, and 3 portions of fruit, $4-5$ portions of vegetables or greens and 7-8 portions of cereals and legumes (a portion is defined as the amount of food that would be found on a usual plateful or the common units of consumption of a food item).

\section{References}

1 Picciano MF. Embarazo y lactancia. In: Ziegler EE, Filer LJ, eds. Conocimientos Actuales Sobre Nutrición. ILSI. Washington: Organización Panamericana de la Salud, 1997; 410-22.

2 Departamento de Nutrición. Tablas de Ingestas Recomendadas de Energía y Nutrientes para la Población Española. Madrid: Departamento de Nutrición, 1994.

3 Ortega RM, Gaspar MJ, Moreiras O. Dietary assessment of a pregnant Spanish women group. Int. J. Vit. Nutr. Res. 1994; 64: $130-4$.

4 Ortega RM, Martínez RM, López-Sobaler AM, Andrés P, Quintas ME. The consumption of food energy and nutrients in pregnant women: differences with respect to smoking habits. Nutr. Res. 1998; 18: 1691-701.

5 Prentice A. Maternal calcium requirements during pregnancy and lactation. Am. J. Clin. Nutr. 1994; 59: 477S-82S

6 Ortega RM, Martínez RM, Quintas ME, López-Sobaler AM,
Andrés P. Calcium levels in maternal milk: relationships with calcium intake during the third trimester of pregnancy. Br. J. Nutr. 1998; 79: 501-7.

7 Ortega RM, Martínez RM, López-Sobaler AM, Andrés P, Quintas ME. The influence of calcium intake on gestational hypertension. Ann. Nutr. Metab. 1999; 43: 37-46.

8 Böhles H. Antioxidative vitamins in prematurely and maturely born infants. Int. J. Vit. Nutr. Res. 1997; 67: 321-8.

9 Ortega RM, Quintas ME, Martínez RM, Andrés P, LópezSobaler AM, Requejo AM. Riboflavin levels in maternal milk: the influence of vitamin $\mathrm{B}_{2}$ status during the third trimester of pregnancy. J. Am. Coll. Nutr. 1999; 18: 324-9.

10 Errasti T, López G, Zazpe I, Muñoz M. La nutrición durante el embarazo. In: Muñoz M, Aranceta J, García-Jalón I, eds. Nutrición Aplicada y Dietoterapia. Pamplona: Eunsa (Ediciones Universidad de Navarra), 1999; 513-38.

11 Allen L, Casterline JE. Safe diet for pregnancy. In: Sadler MJ, Strain JJ, Caballero B, eds. Encyclopaedia of Human Nutrition. San Diego, CA: Academic Press, 1999; 1599-605.

12 Smolin LA, Grosvenor MB. In the beginning: nutrition for mothers and infants. Nutrition. Science \& Applications. Philadelphia, PA: Saunders College Publishing, 1999; 42359.

13 Larrañaga IJ, Carballo M, Rodríguez MM, Fernández JA. Dietética y Dietoterapia. Madrid: McGraw-Hill, 1997; 18292.

14 Ensminger AH, Ensminger ME, Konlande JE, Robson JRK. The Concise Encyclopaedia of Foods \& Nutrition. London: CRC Boca Raton, 1995.

15 Institute of Medicine, Food and Nutrition Board. Dietary Reference Intakes for Thiamine, Riboflavin, Niacin, Vitamin B-6, Folate, Vitamin-B-12, Pantothenic Acid, Biotin and Choline. Washington, DC: National Academy Press, 1998.

16 Ortega RM, López-Sobaler AM, Martínez RM, Andrés P, Quintas ME. The influence of smoking on vitamin E status during the third trimester of pregnancy and on breast milk tocopherol concentrations in Spanish women. Am. J. Clin. Nutr. 1998; 68: 662-7.

17 Ortega RM, Quintas ME, Andrés P, Martínez RM, LópezSobaler AM. Ascorbic acid levels in maternal milk: the influence of ascorbic acid status during the third trimester of pregnancy. Br.J. Nutr. 1998; 79: 431-7.

18 Ortega RM, López-Sobaler AM, Quintas ME, Martínez RM, Andrés P. The influence of smoking on vitamin C status during the third trimester of pregnancy and on vitamin C levels in maternal milk. J. Am. Coll. Nutr. 1998; 17: 379-84.

19 Ortega RM, Requejo AM, López-Sobaler AM. Conocimiento respecto a las características de una dieta equilibrada y su relación con los hábitos alimentarios de un colectivo de jóvenes universitarios. Nutr. Clin. 2000; 20: 19-25. 